\title{
Vascular Stem Cells in Vascular Remodeling and Diseases
}

\author{
Anna Meiliana ${ }^{1,2, *}$, Andi Wijaya ${ }^{1,2}$ \\ ${ }^{1}$ Postgraduate Program in Clinical Biochemistry, Hasanuddin University, Jl. Perintis Kemerdekaan Km.10, Makassar, Indonesia \\ ${ }^{2}$ Prodia Clinical Laboratory, Jl. Cisangkuy No.2, Bandung, Indonesia \\ *Corresponding author. E-mail: anna.meiliana@prodia.co.id
}

\section{Abstract}

$\mathrm{B}$ ACKGROUND: Blood vessels are a source of stem and progenitor cells, which likely contribute to a variety of vascular processes and diseases. Emerging concepts in this field could influence therapeutic approaches to diseases of blood vessels such as atherosclerosis.

CONTENT: Vascular Stem Cells (VSCs) field is only beginning to emerge, and thus, many issues regarding VSCs's identity and function remain poorly understood. In fact, even after decades of intensive research, Mesenchymal Stem Cells (MSC), which is suggested to be VSCs, is still having many outstanding issues of its own. And, on top of this, likewise decades-long intensive pericyte research has not been able resolve the identity issue. While favors Adventitial Progenitor Cells (APCs) over pericytes as the likely VSC candidate, it should be pointed out that currently the opposite view (i.e., pericytes as VSCs) is more prevalent, and many excellent reviews, including a recent one, have discussed this issue extensively.

SUMMARY: It has been postulated that, within the vasculature, APCs could differentiate into pericytes (CD34$\left.\mathrm{CD} 31^{-} \mathrm{CD} 140 \mathrm{~b}^{+} \mathrm{SMA}^{-}\right)$, endothelial cells $\left(\mathrm{CD} 34^{+} \mathrm{CD} 31^{+}\right.$ $\mathrm{CD} 140 \mathrm{~b}^{-} \mathrm{SMA}^{-}$), and smooth muscle cells (SMCs) (CD34$\mathrm{CD} 31^{-} \mathrm{CD}^{-} 40 \mathrm{~b}^{-} \mathrm{SMA}^{+}$); and during tissue expansion or repair, APCs could also differentiate into tissue-specific cell types (e.g., muscle and fat) Thus, in vitro, APCs fulfill all criteria for being VSCs. Meanwhile, in vivo evidence is still limited and will require further investigation.

KEYWORDS: vascular stem cells, VSC, mesenchymal stem cells, MSC, endothelial progenitor cells, EPC, adventitial progenitor cells, APC

\section{Abstrak}

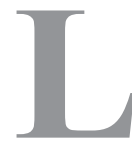

ATAR BELAKANG: Pembuluh darah merupakan sumber sel punca dan sel progenitor, yang banyak berperan dalam berbagai proses dan penyakit vaskular. Konsep ini dapat mempengaruhi pendekatan terapi penyakit pembuluh darah seperti aterosklerosis.

ISI: Ketertarikan para ilmuwan akan Vascular Stem Cells (VSCs) baru akhir-akhir ini, sehingga pemahaman mengenai VSCs dan fungsinya masih sangat kurang. Penelitian Mesenchymal Stem Cells (MSCs) selama beberapa dekade terakhir, yang diduga adalah VSCs, belum mendapatkan titik temu. Penelitian yang intensif selama beberapa dekade mengenai pericyte juga tidak dapat memecahkan masalah ini. Artikel ini menggambarkan bahwa Adventitial Progenitor Cells (APCs) merupakan kandidat kuat sebagai VSCs dibanding pericyte, dengan tidak mengesampingkan pendapat yang menyatakan bahwa VSCs adalah pericyte.

RINGKASAN: Telah diketahui bahwa di dalam pembuluh darah, APCs dapat berdiferensiasi menjadi pericyte (CD34$\left.\mathrm{CD}^{-} 1^{-} \mathrm{CD}_{140 b^{+}} \mathrm{SMA}^{-}\right)$, sel endotel $\left(\mathrm{CD} 34^{+} \mathrm{CD}^{+} 1^{+}\right.$

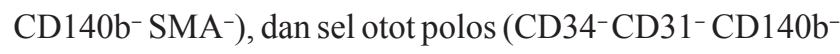
$\mathrm{SMA}^{+}$); dan selama perkembangan atau perbaikan jaringan, APCs juga dapat berdiferensiasi menjadi tipe sel spesifik sesuai jaringan (misalnya, sel otot atau lemak). Jadi secara in vitro, APCs memenuhi kriteria sebagai VSCs. Namun secara in vivo, buktinya masih sedikit dan membutuhkan penelitian lebih lanjut.

KATA KUNCI: vascular stem cells, VSC, mesenchymal stem cells, MSC, endothelial progenitor cells, EPC, adventitial progenitor cells, APC 


\section{Introduction}

The concept that stem cells reside in adult tissues, where they influence normal homeostasis and disease progression, has revolutionized paradigms of physiology and pathology. This is especially true for vascular system, which is associated with stem and progenitor cells in several ways. $(1,2,3)$

Various cell types that make up vasculature, do not arise from a single embryonic source, and cells from multiple sources can ultimately acquire the same fate. $(4,5)$ Given that blood vessels are found associated with virtually every organ and tissue in the body, it makes sense that local tissues provide precursor cells. Thus, vasculature has multiple cell types and does not arise homogeneously but is rather a mosaic of cells from different sources and locales. This diverse etiology may influence vascular function and disease propensity.(3)

"Vascular stem cells" (VSCs) as a biomedical term first appeared more than 10 years ago, and their existence in humans and experimental animals was demonstrated another decade earlier. Granted, these cells remain poorly understood and not well known even in stem cell research field. VSCs is defined in this article as "cells that reside within the blood vessel wall and can differentiate into all of cell types that constitute a functional blood vessel." Specifically, VSCs can differentiate into endothelial cells (ECs) and pericytes in capillary, and additionally, smooth muscle and adventitial cells in larger vessels.(6) Regulation of stem cell populations affects their recruitment, differentiation, spatial organization, and their coordination with host tissue. Loss and dysregulation of feedback control cause a variety of diseases that involve ectopic tissue formation, including atherosclerotic lesion formation and calcification, diabetic vasculopathies, and arteriovenous malformations.(7)

This article overviews the spectrum of VSCs that have been documented in macro- and micro-vessels during developmental and adult life, and consideres the implications for a local, vascular wall stem cell niche(s) in the pathogenesis and treatment of cardiovascular and other diseases.

\section{Stem Cells and Vasculature}

Vasculature is a constantly adapting tissue, that penetrates every other organ in the body except cornea and cartilage. Consequently, vascular disease has the potential to affect all organs and tissues. Tissue repair and regeneration will also have to involve vasculature, where it may even be initiated or triggered. These features make vasculature itself an ideal site to place stem cells strategically in pools that can be expanded rapidly to respond to injury and disease. This hypothesis suggests an interesting interface, where stem cell biology could greatly contribute to our understanding in the role of stem cells in vascular disease.(7)

Blood vessels are composed of ECs that provide the inner (luminal) surface of the vessel in contact with blood, and mural cells that interact with the outer (abluminal) surface of ECs. Mural cells most often are pericytes, and the vessel wall of the vast majority of vessels in body, which comprise microcirculation, consists simply of ECs surrounded by pericytes. Larger vessels, especially arterioles, arteries and veins, are invested with SMCs and elastic fibers that provide contractility, and larger arteries and veins also have an organized structure of fibroblasts that produce collagen.(3) The diverse embryonic sources of both ECs and mural cells argue against a single type of VSCs, analogous to the hematopoietic stem cell, which would both self-renew and contribute to all vascular lineages. It can also be argued that there is no need for a VSC, as once ECs differentiate they retain the capacity to proliferate and form new vessels via sprouting angiogenesis, and mesenchymal cells capable of recruitment to mural lineages reside in most local environments. However, both vascular compartmentsendothelial and mural are associated with stem cells, progenitor cells or both during development.(8-10)

Vascular structures are unique. They are expected to take up little space and at the same time perfuse and deliver nutrients to all locations in the body. Thus, they will have to show inventiveness in penetrating organs and adapting to the spatial structure of each organ. Considering the stringent space restrictions, it is an interesting problem how stem cells are provided locally for repair or for the development of new vessels. Strategies will be needed to keep the number of progenitor cells low, yet keep them available for rapid mobilization and expansion.(11,12) Stem cell pools may be one way that the vasculature responds to these requirements. Stem cells are often found near basement membrane, which has suggested the existence of so-called "niches" or specialized microenvironments for stem cells. $(13,14)$

A cell population in proximity to the basement membrane would be perfectly located to supply both ECs and smooth muscle cells (SMCs) progenitor cells, enabling quick regeneration. The origin of such progenitor cells would include resident vascular as well as circulating stem cells. Resident stem cells may be reserved and positioned during development(15), whereas circulating stem cells, mainly derived from the bone marrow $(\mathrm{BM})(16,17)$, may be rapidly mobilized from the circulation and modified by the vascular context. There is dramatic evidence of multipotent 
cells in the vasculature, especially in vascular calcification and ectopic bone formation. $(18,19)$ Multiple studies have demonstrated that vascular mesenchymal cells, including microvascular pericytes, so-called calcifying vascular cells and SMCs, undergo osteochondrogenic lineage differentiation spontaneously or under special conditions such as hyperphosphatemia. $(18,20)$

In recent times, these traditional views of vascular biology have been revised by the discovery of immature stem/progenitor cell populations, relevant to endothelial(21,22), smooth muscle(23-25), myeloid(26) and multipotent mesenchymal lineage(27) that have been shown to participate in postnatal vasculogenesis and vascular wall remodeling. An increasing body of evidence points to the existence of these different progenitor cell types within embryonic, fetal and adult vessel walls, where they may reside either constitutively or appear as a result of circulating migration.(2) Thus, the stem cell biologist could greatly support vascular biology with knowledge of how to reverse terminal differentiation toward more stem cell-like characteristics, and the relation between stages of differentiation and the patterning of tissues, all central in vascular regeneration and disease.

\section{Angiogenesis and "Vasculogenic Zone"}

Development of vasculature and its subsequent homeostasis are integral components of embryogenesis, fetal organogenesis, maintenance of health and normal function of adult tissues. In embryonic life, emergence of ancestral stem/progenitor cells for both ECs and hematopoietic cells gives rise to the formation of blood vessels, which are then stabilized by incorporation of peri-ECs and stromal elements. (28) New blood vessel formation (neovascularization) also continues in adults and is a key contributor to both physiological and pathological processes, including tissue ischemia, repair and regeneration, atherosclerosis, tumor growth and metastasis.(1)

Postnatal vascular wall comprises three concentric layers consisting of a limited number of cell types. Tunica intima has an EC lining which interfaces with blood, media contains several layers of SMCs, and adventitia is made up of stromal and adipose tissue, along with the vasa and nerva vasorum. Disruption of vessel wall integrity is associated with pathogenesis of various disease processes, including atherosclerosis, aneurysm formation, vasculitis, allograft vasculopathy and post-intervention restenosis, which in turn may occlude tissue blood supply, leading to ischemia or infarction.(2) Up until the last decade, it was widely believed that cellular elements of adult vessel wall are terminally differentiated and thus relatively quiescent. Angiogenesis, defined as the formation of new blood vessels from preexisting ECs, was considered to be the only mechanism by which neovascularization occurred after birth.(1)

Main steps of this process comprise ECs migration, proliferation and tube formation. Accumulating data indicate a role for circulating endothelial precursor cells and/ or BM-derived endothelial precursor cells involved in the new blood vessel formation(21,29-32), a process defined as postnatal vasculogenesis. More recent data suggest a role for tissue-bound precursor cells as source of vascular cells and concomitantly accumulating macrophages during collateral vessel growth.(33) The existence of local tissue-bound adult precursor cells has been reported for different organs $(34,35)$, but not yet for the wall of adult blood vessels(36). Our data suggest the existence of a 'vasculogenic zone' in the adult human vascular wall that is, to our knowledge, the first reported location for endothelial progenitor cells (EPCs) outside the BM, which may serve as a source for progenitor cells for postnatal vasculogenesis, contributing to tumor vascularization and local immune response.(26)

The local activation and migration of vascular wall resident progenitor cells (VW-PCs) is believed to contribute to cell turnover during physiologic and pathogenic vascular remodeling and neovascularization, while there may also be dynamic, bidirectional exchange of progenitor cells between the vessel wall and peripheral circulation throughout adult life.(2)

\section{Atherosclerosis and Diabetic Complications}

Many studies in animals and in humans have demonstrated that various lineages of BM-derived cells in the circulation infiltrate vascular lesions. In addition to vascular progenitor cells, new subsets of immune cells are emerging as important effectors and regulators of immune responses. Moreover, recent studies have unraveled dynamic plasticity in their phenotypes and functions.(37) Recent studies have demonstrated that BM cells also may serve as sources of vascular cell lineages, including EPCs and smooth muscle progenitor cells (SMPCs).(21,38) Although these vascular progenitors originally had been thought to differentiate into mature and functional endothelial and SMCs in physiological and pathological settings(21,37), subsequent studies have reported conflicting results(37). Therefore, it is still unclear whether these cells acquire definitive endothelial and SMC identities. Accordingly, their functional contributions to atherogenesis are still undergoing debate. The development of vascular diseases, such as intimal hyperplasia and atherosclerosis, involves proliferation and migration of vascular cells.(39-42) Vascular SMCs are the predominant cell type in the tunica media of the blood vessel wall. Studies 


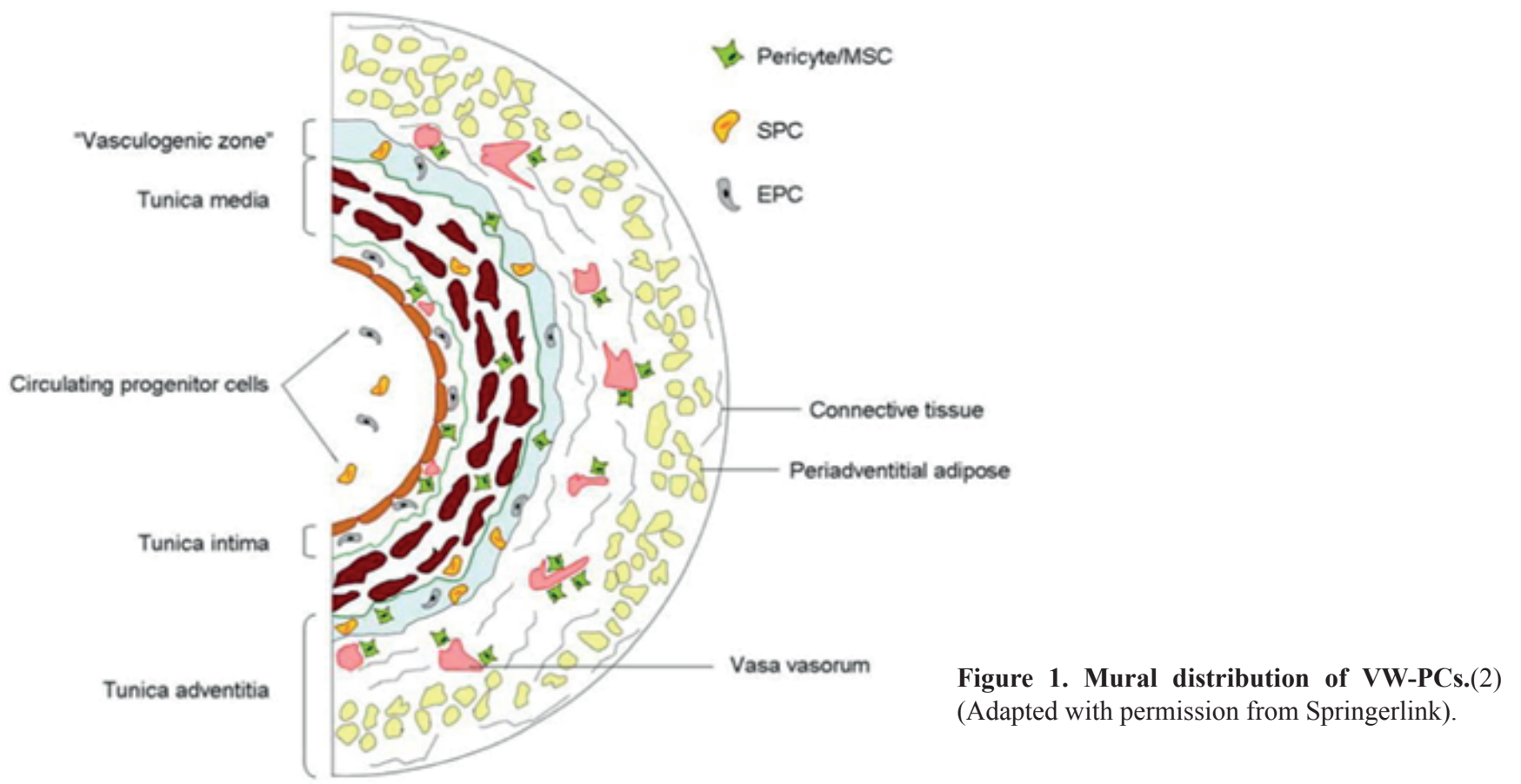

from many laboratories have shown that cultured SMCs and SMCs in the neointima "loose" the expression of smooth muscle myosin heavy chain (SM-MHC), a marker of contractile SMCs, and become proliferative and synthetic. (43-48) A widely accepted explanation is that SMCs have phenotypic plasticity and that mature or contractile SMCs can de-differentiate into proliferative and synthetic SMCs 4.(49-51) However, this de-differentiation process has not been directly demonstrated by tracking the fate of mature or contractile SMCs.

Tang, et al. provide evidence that challenges this theory. They identify a new type of multipotent vascular stem cell (MVSC) in blood vessel wall. MVSCs express markers including Sox17, Sox 10 and S100 $\beta$, are cloneable, have telomerase activity, and can differentiate into neural cells and MSC-like cells that subsequently differentiate into SMCs.(52) Upon vascular injuries, MVSCs, instead of
SMCs, become proliferative, and MVSCs can differentiate into SMCs and chondrogenic cells, thus contributing to vascular remodeling and neointimal hyperplasia. These findings support a new hypothesis that the differentiation of MVSCs, rather than the de-differentiation of SMCs, contributes to vascular remodeling and diseases.(52) These findings provide unprecedented insight into the role of stem cells in vascular diseases and remodeling, which suggests that vascular diseases are stem cell diseases. These findings may have transformative impact on vascular biology and diseases, and may lead to new therapies by using VSCs as a therapeutic target.

Angiogenesis, the predominant form of neovascularization in atherosclerosis, is mediated by ECs sprouting from postcapillary venules, leading primarily to new capillaries.(53) The molecular mechanisms responsible for neovessel formation are related predominantly to hypoxia.

Adult Vascular Wall Resident Stem Cells / Endothelial Precursor Cells

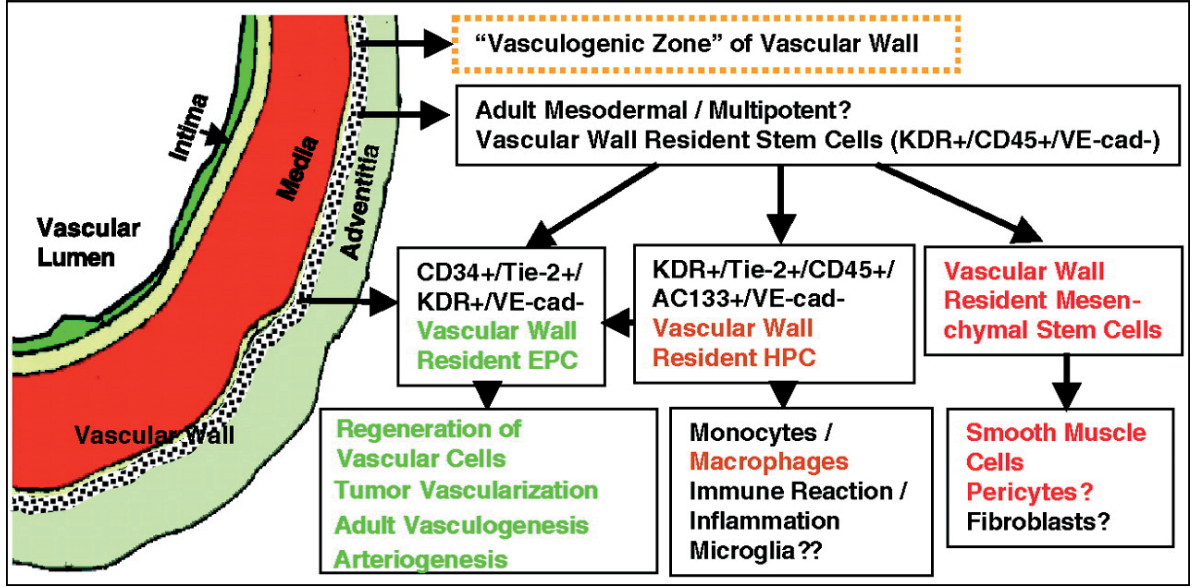

Figure 2. Hypothetical scheme of the 'vasculogenic zone'.(21) (Adapted with permission from The Company of Biologist Ltd). 


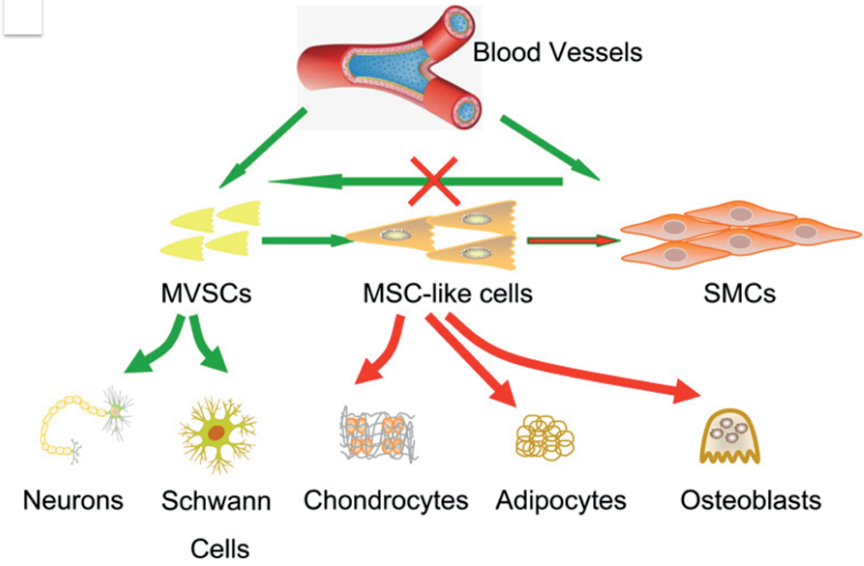

More recently, hypoxia-independent pathways have also been described, mediated primarily by inflammation and activation of the toll-like receptor.(54)

On the basis of the aforementioned observations, it is reasonable to develop the following hypothesis: Adventitial -derived vasa vasorum neovascularization develops under the trigger of oxidized low-density lipoprotein deposits in the intima, mediated by hypoxia and toll-like receptors. Such neovessels may contribute to the removal of intimal fat when the concentration of low-density lipoprotein is lower in the neovessel circulation than in the intima (lowdensity lipoprotein concentration gradient). However, extravasation of red blood cells (RBCs) from leaky neovessels attracts macrophages to the field, both at the intima-media junction and the shoulders of the plaque. Macrophage erythrophagocitosis leads to cell activation at these crucial sites of the plaque. Then macrophage-derived matrix metalloproteinase secretion leads to rupture of the internal elastic lamina(55) and fibrous cap collagenolysis, precipitating plaque rupture and thrombosis(56).

Diabetes mellitus, through the impairment of vascular stem and progenitor cells entails a defective repair of the injured endothelium.(58) To stop the progression of these complications and to repair the damage, we would need to either replace the damaged ECs or create brand new vascular networks. Considering mounting evidence of stem/ progenitor cells in various tissues including the blood vessel wall(50), we can speculate that the reason diabetic patients exhibit impaired repair mechanisms is because these stem/ progenitor cells are also affected(60). Ideally, it would be one cell type or a subpopulation that can produce both ECs and the supportive perivascular cells. The notion of a specific VSC able to produce mature/functional cells of the blood vessels is slowly gaining momentum.

The exact identity of the VSCs is still not clear. There is ample evidence that these VSCs are found in the BM and
Figure 3. Schematic illustration of the spontaneous differentiation of MVSCs and the differentiation potential of the cells at different stages.(52) (Adapted with permission from Nature Publishing Group).

circulation and are quite distinct from hematopoietic stem cells. Selection of cluster of differentiation (CD) $133^{+}$cells from the circulation purifies a population(s) of cells that under different culture conditions, will produce lineagerestricted EPCs and mesenchymal/mesodermal progenitor cells (MPCs).(61-65) The vascular changes that occur in diabetic complications highlighting some of the common features, the key findings that illustrate an important role of VSCs in the pathogenesis of chronic diabetic complications, and provide mechanisms by which these cells can be used for therapy.

\section{What are Vascular Stem Cells?}

MSCs exist in most adult tissues and have been located near or within blood vessels. Although "perivascular" has been commonly used to describe such locations, increasing evidence points at the vessel wall as the exact location. Thus, VSCs is recommended as a more accurate term for MSCs. Furthermore, 2 cell populations, namely pericytes and Advential Progenitor Cells (APCs), are the likely VSCs. The pericyte evidence relies on the so-called pericytespecific markers, but none of these markers is pericyte specific. In addition, pericytes appear to be too functionally diverse and sophisticated to have a large differentiation capacity. On the other hand, APCs are more nave functionally and, therefore, more akin to being VSCs. These cells spontaneously in vitro-differentiate into pericytes, and can be induced to differentiate into vascular cells (ECs and SMCs) and mesenchymal cells (e.g., bone, cartilage, and fat).(6)

While EPCs are defined as originating from BM and circulating in the blood, "true" VSCs (as defined earlier, in introduction) are expected to reside within the blood vessel wall. At this location, 3 distinct cell types exist: ECs and pericytes in capillaries, and additionally, SMCs in larger vessels. In addition, a mixed population of cells 
(macrophages, dendritic cells, fibroblasts, and progenitor cells) resides in the adventitia. $(66,67)$ The possibilities for these vessel wall cells to be stem or progenitor cells have been reviewed, for example, in these recent articles. $(2,3,7,15,66-72)$ In particular, pericytes and APCs have emerged as the most plausible VSCs.

Pericytes, the mural cells of blood microvessels, have recently come into focus as regulators of vascular morphogenesis and function during development, cardiovascular homeostasis and disease. Pericytes are implicated in the development of diabetic retinopathy and tissue fibrosis, and they are potential stromal targets for cancer therapy. Some pericytes are probably MSCs or progenitor cells, which give rise to adipocytes, cartilage, bone and muscle. However, there is still confusion about the identity, ontogeny, and progeny of pericytes.(73) Pericytes and ECs are intimately connected by tight and gap junctions, and each pericyte may be in contact with several ECs via elongated processes wrapping around and along the blood vessel.(74,75) In larger vessels, pericytes may be observed not only as sub-ECs in the inner intimal layer, but also in the media and adventitia associated with the vasa vasorum.(76)

Evidence is accumulating to suggest a close relationship between MSCs and pericytes. Conceivably, given that MSCs (and pericytes) isolated from disparate tissues exhibit subtle variability in differentiation capability, it is possible that MSCs are ubiquitous perivascular progenitor cells distributed throughout the body, but with a degree of lineage allegiance to their host tissue.(68) Conventional views of the tunica adventitia as a poorly organized layer of vessel wall composed of fibroblasts, connective tissue, and perivascular nerves are undergoing revision. Recent studies suggest that the adventitia has properties of a stem/progenitor cell niche in the artery wall that may be poised to respond to arterial injury. It is also a major site

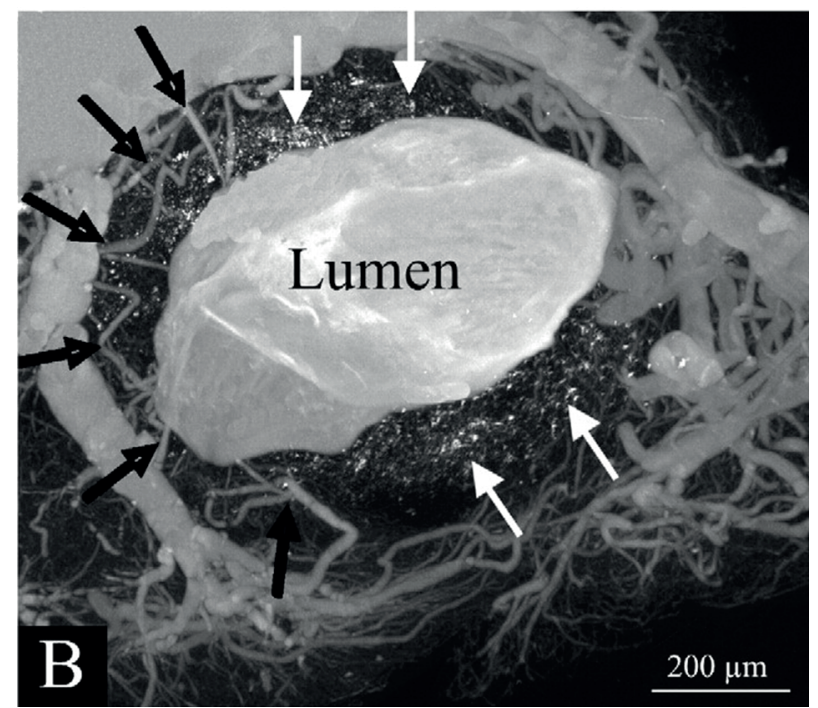

of immune surveillance and inflammatory cell trafficking and harbors a dynamic microvasculature, the vasa vasorum, that maintains the medial layer and provides an important gateway for macrophage and leukocyte migration into the intima. In addition, the adventitia is in contact with tissue that surrounds the vessel and may actively participate in exchange of signals and cells between the vessel wall and the tissue in which it resides.(30)

Unlike the media and intima, which are synonymic with smooth muscle and endothelium, respectively, the adventitia does not have a defined synonymic cell type. However, when an artery's cross-section is stained for CD34, 2 concentric rings of cells corresponding to the intima and adventitia are revealed. The inner ring is thin, compact, and complete, and is undoubtedly the endothelium that also stains positive for CD31. The outer ring, which is outside of the media and thus belongs to the adventitia, is irregular, loose, incomplete, and distinctively CD31-. This population of $\mathrm{CD} 34^{+} \mathrm{CD} 31^{-}$adventitial cells is now increasingly believed to be VSCs. $(26,77,78)$

Therefore, the adventitia consists of a complex community of interacting cell types, and abundant evidence now indicates that a better understanding of molecular mechanisms for homeostasis, repair, and disease of the vessel wall will require a greater appreciation of the integrated role of the adventitia with the intimal and medial layers. This population of $\mathrm{CD} 34^{+} \mathrm{CD} 31^{-}$adventitial cells was also said to exist in all of the human organs studied, including urinary bladder, testis, prostate, kidney, lung, heart, liver, and brain, the term "vasculogenic zone" to denote the CD $34^{+}$ CD31- ring in the adventitia of human blood vessels, and suggested that the $\mathrm{CD} 34^{+} \mathrm{CD} 31^{-}$cells might be progenitor cells for postnatal vasculogenesis. MSC-like cells residing in the same vasculogenic zone were shown to be $\mathrm{CD} 44^{+}$but CD34-.(79)

A recent study provided strong evidence that native MSCs in BM lack CD44 expression.(80) Thus, equating the CD44+ ${ }^{+}$D34- adventitial cells with MSCs will require stronger evidence. In 2004, $\mathrm{Hu}$ et al.(24) reported the identification of cells that stained positive for cell markers Spinocerebellar Ataxia 1 (Sca1), c-kit, CD34, and for Fetal Liver Kinase 1 (Flk1) in the adventitia of mouse aorta. When transferred to the adventitial side of vein grafts in Apolipoprotein E (ApoE)-deficient mice, Sca1-expressing adventitial cells were found in atherosclerotic lesions of the intima. The authors thus concluded that a population of

Figure 4. Micro-CT transaxial images of a double knockout mouse (LDL-/-, apoE-/-) aorta after it was injected with a radiopaque silicon polymer.(57) (Adapted with permission from Elsevier BV). 
vascular progenitor cells in the adventitia could differentiate into SMCs which contribute to atherosclerosis.(6)

The Sca1 expression mentioned earlier in the adventitia has been independently confirmed in mouse aorta and mesenteric and femoral arteries.(25) More importantly, $\mathrm{Sca}^{+}$cells immune-selected from the aortic adventitia were found capable of smooth muscle and endothelial differentiation. Moreover, when the Scal-selected cells were treated with Bone Morphogenetic Protein 2 (BMP2), colonies formed that stained positive by alizarin red, suggesting osteogenic differentiation. These findings thus reinforced the existence of APCs.(6) Indeed, pericytes' functions are more than blood flow regulation, but as diverse as performing vessel stabilization, vascular tone regulation, vessel permeability regulation, local tissue homeostasis maintenance, macrophage-like properties, immunologic defense, coagulation intervention, and control of the quiescent and angiogenic stages of blood vessels. (81) Thus, with these large degrees of functional diversity and sophistication, how can pericytes still maintain a large capacity for differentiation, including the ability to become many different cell types with each having its own sophisticated functions. On the other hand, APCs are not known to have any specific physiological function and are, thus, developmentally more akin to primitive cells whose primary role is serving as progenitors for various specialized cell types. In the capillary, which lacks a defined adventitia, the APC equivalent still exists, as evidenced by the presence of the same CD34+ ${ }^{+}$D $31^{-}$CD140b ${ }^{-}$SMA $^{-}$cells in both the adventitia and the capillary. $(78,82)$

Thus, it has been postulated that, within the vasculature, APCs could differentiate into pericytes (CD34- CD31-

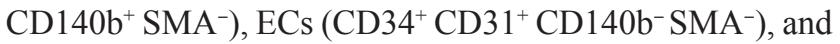
SMCs (CD34- $\left.{ }^{-}{ }^{-} 31^{-} \mathrm{CD}^{-} 140 \mathrm{~b}^{-} \mathrm{SMA}^{+}\right)$; and during tissue expansion or repair, APCs could also differentiate into tissue-specific cell types (e.g., muscle and fat). $(78,82)$ As defined earlier, VSCs reside within the vessel wall and can differentiate into all cell types that constitute a functional blood vessel. They can probably also differentiate into specific mesenchymal cells of their native tissue, or they can induce the replication/differentiation of such cells via growth factor secretion. Consistent with these proposed VSC characteristics, APCs are the most likely candidates for being VSCs. Thus, in vitro, APCs fulfill all criteria for being VSCs. Meanwhile, in vivo evidence is still limited and will require further investigations.(6)

\section{Vascular Stem Cells and Therapeutic Promise}

Now, it is widely accepted that atherosclerosis is a chronic inflammatory disease. $(39,83)$ Chronic inflammatory processes alter the 3-dimensional structure of the vascular wall (vascular modeling), leading to the atherosclerotic plaque formation.(84) $\mathrm{CD} 34^{+} \mathrm{CD} 31^{-} \mathrm{CD} 146^{-} \mathrm{CD}^{-} 5^{-}$cells residing in tunica adventitia of arteries and veins yield in culture multipotent progenitors functionally and antigenically to MSC. Coincidentally, the tunica adventitia is believed to play a role in vascular remodeling and be involved in the development of atherosclerosis.(85-88) Adventitial cells indeed proliferate, differentiate into myofibroblasts, and migrate into the inner layer of blood vessels in response to injury or stress. $(24,89-92) \mathrm{CD} 34^{+} \mathrm{CD} 31^{-}$cells located in the "vasculogenic zone" of the thoracic artery, between the tunica media and tunica adventitia, can also give rise to endothelium; hence, they could represent a resident pool of EPCs for postnatal vasculogenesis.(26)

The vessel wall has a substantial intrinsic capacity for wound repair. Under normal conditions, the artery wall in adult animals has very low to undetectable rates of ECs or SMC proliferation. When subjected to overstretch injury, however, proliferation rates in all layers of artery wall can increase more than 100-fold. $(47,93)$ Because of its location between the vessel wall and the surrounding tissues in which the vessel is located, adventitial cells could, in principle, participate in tissue repair or disease processes in either the vessel wall itself or in surrounding nonvascular tissues.(67) An early event observed following many forms of arterial injury is adventitial inflammation and an accumulation of monocytes and activated macrophages in the adventitia.(9496) This local inflammatory response may be necessary for down-regulation of the ongoing adventitial niche signaling that maintains $\mathrm{Sca}^{+}$cells as progenitors, thus resulting in the "release" of these progenitor cells to adopt other cell fates.

Direct evidence for the capability of adventitial cells to migrate through the media and into the intima has been obtained by transplanting cells onto the adventitial side of an artery and monitoring movement of these cells following arterial injury. $(24,90,97,98)$ In addition, an intriguing possibility is that adventitial Sca1+ progenitor cells may be stimulated by arterial injury to adopt an SMC-like phenotype and migrate into the media and possibly into the intima, and thereby participate in neointimal formation. $(24,25)$ Development of new cell therapeutics based on detailed understanding of generation of VSCs holds great promise.

Whereas uncertainties concerning cell lineages and identities remain, there is sufficient available information to consider a scenario in which VSCs play critical physiological roles in vascular development and homeostasis, as sources of fibrogenic cells in pathological situations, and as a possible 
reservoir of stem or progenitor cells for adult vascular repair. In the future, defining the mechanisms regulating vascular development would be the fundamental for treating vascular diseases.

\section{Conclusion}

VSCs is defined as "cells that reside within the blood vessel wall and can differentiate into all of the cell types that constitute a functional blood vessel." Specifically, the cell types that VSCs can differentiate into include ECs and pericytes in the capillary, and additionally, smooth muscle and adventitial cells in larger vessels. They can probably also differentiate into specific mesenchymal cells of their native tissue, or they can induce the replication/differentiation of such cells via growth factor secretion. Consistent with these proposed VSC characteristics, APCs are the most likely candidates for being VSCs.

These findings provide unprecedented insight into the role of stem cells in vascular diseases and remodeling, which suggests that vascular diseases are stem cell diseases. These findings may have transformative impact on vascular biology and diseases, and may lead to new therapies by using VSCs as a therapeutic target.

\section{References}

1. Carmeliet P, Jain RK. Molecular mechanisms and clinical applications of angiogenesis. Nature. 2011; 473: 298-307.

2. Psaltis PJ, Harbuzariu A, Delacroix S, Holroyd EW, Simari RD Resident vascular progenitor cells-diverse origins, phenotype and function. J Cardiovasc Transl Res. 2011; 4: 161-76.

3. Bautch VL. Stem Cells and the vasculature. Nat Med. 2011; 17: 143743.

4. Hogan KA, Bautch VL. Blood vessel patterning at the embryonic midline. Curr Top Dev Biol. 2004; 62: 55-85.

5. Majesky MW. Developmental basis of vascular smooth muscle diversity. Arterioscler Thromb Vasc Biol. 2007; 27: 1248-58.

6. Lin CS, Lue TF. Defining vascular stem cells. Stem Cells Dev. 2013; 22: $1018-26$.

7. Boström KI, Garfinkel A, Yao Y, Jumabay M. Concise review: Applying stem cell biology to vascular structure. Stem Cells. 2012; 30: 38691.

8. Bianco P, Robey PG, Simmons PJ. Mesenchymal stem cells: revisiting history, concepts and assays. Cell Stem Cell. 2008; 2: 313-9.

9. Park C, Ma YD, Choi K. Evidence for the hemangioblast. Exp Hematol 2005; 33: 965-70.

10. Wu SM, Chien KR, Mummery C. Origins and fates of cardiovascular progenitor cells. Cell. 2008; 132: 537-43.

11. Lander AD. Pattern, growth, and control. Cell. 2011; 144: 955-69.

12. Lander AD, Gokoffski KK, Wan FY, Nie Q, Calof AL. Cell lineages and the logic of proliferative control. PLoS Biol. 2009; 7: 15.

13. Nikolova G, Strilic B, Lammert E. The vascular niche and its basement membrane. Trends Cell Biol. 2007; 17: 19-25.
14. Watt FM, Hogan BL. Out of Eden: Stem cells and their niches. Science. 2000; 287: 1427-30.

15. Torsney E, Xu Q. Resident vascular progenitor cells. J Mol Cell Cardiol. 2011; 50: 304-11.

16. Dimmeler S. Regulation of bone marrow-derived vascular progenitor cell mobilization and maintenance. Arterioscler Thromb Vasc Biol. 2010; 30: 1088-93

17. Tanaka K, Sata M. Contribution of circulating vascular progenitors in lesion formation and vascular healing: Lessons from animal models. Curr Opin Lipidol. 2008; 19: 498-504.

18. Sage AP, Tintut Y, Demer LL. Regulatory mechanisms in vascular calcification. Nat Rev Cardiol. 2010; 7: 528-36.

19. Boström KI, Rajamannan NM, Towler DA. The regulation of valvular and vascular sclerosis by osteogenic morphogens. Circ Res. 2011; 109: 564-77.

20. Shanahan CM, Crouthamel MH, Kapustin A, Giachelli CM. Arterial calcification in chronic kidney disease: Key roles for calcium and phosphate. Circ Res. 2011; 109: 697-711

21. Asahara T, Murohara T, Sullivan A, Silver M, van der Zee R, Li T, et al. Isolation of putative progenitor endothelial cells for angiogenesis. Science. 1997; 275: 964-7.

22. Ingram DA, Mead LE, Moore DB, Woodard W, Fenoglio A, Yoder MC. Vessel wall-derived endothelial cells rapidly proliferate because they contain a complete hierarchy of endothelial progenitor cells. Blood. 2005; 105: 2783-6.

23. Simper D, Stalboerger PG, Panetta CJ, Wang S, Caplice NM. Smooth muscle progenitor cells in human blood. Circulation. 2002; 106:1 199-204.

24. Hu Y, Zhang Z, Torsney E, Afzal AR, Davison F, Metzler B, et al. Abundant progenitor cells in the adventitia contribute to atherosclerosis of vein grafts in ApoE-deficient mice. J Clin Invest. 2004; 113: 1258-65.

25. Passman JN, Dong XR, Wu SP, Maguire CT, Hogan KA, Bautch VL, et al. A sonic hedgehog signaling domain in the arterial adventitia supports resident $\mathrm{Sca}^{+}{ }^{+}$smooth muscle progenitor cells. Proc Natl Acad Sci U S A. 2008; 105: 9349-54.

26. Zengin E, Chalajour F, Gehling UM, Ito WD, Treede H, Lauke H, et al. Vascular wall resident progenitor cells: a source for postnatal vasculogenesis. Development. 2006; 133: 1543-51.

27. Tintut Y, Alfonso Z, Saini T, Radcliff K, Watson K, Boström K, Demer LL. Multilineage potential of cells from the artery wall. Circulation. 2003; 108: 2505-10.

28. Tavian M, Zheng B, Oberlin E, Crisan M, Sun B, Huard J, et al. The vascular wall as a source of stem cells. Ann N Y Acad Sci. 2005; 1044: 41-50.

29. Asahara T, Isner JM. Endothelial progenitor cells for vascular regeneration. J Hematother Stem Cell Res. 2002; 11: 171-8.

30. Gehling UM, Ergün S, Schumacher U, Wagener C, Pantel K, Otte M, et al. In vitro differentiation of endothelial cells from AC133-positive progenitor cells. Blood. 2000; 95: 3106-12.

31. Grant MB, May WS, Caballero S, Brown GA, Guthrie SM, Mames $\mathrm{RN}$, et al. Adult hematopoietic stem cells provide functional hemangioblast activity during retinal neovascularization. Nat Med. 2002; 8: 607-12

32. Pelosi E, Valtieri M, Coppola S, Botta R, Gabbianelli M, Lulli V, et al. Identification of the hemangioblast in postnatal life. Blood. 2002; 100: 3203-8.

33. Khmelewski E, Becker A, Meinertz T, Ito WD. Tissue resident cells play a dominant role in arteriogenesis and concomitant macrophage accumulation. Circ Res. 2004; 95: 56-64

34. Aarum J, Sandberg K, Haeberlein SL, Persson MA. Migration and differentiation of neural precursor cells can be directed by microglia. Proc Natl Acad Sci USA. 2003; 100: 15983-8. 
35. Conboy IM, Conboy MJ, Smythe GM, Rando TA. Notch-mediated restoration of regenerative potential to aged muscle. Science. 2003; 302: 1575-7.

36. Asahara T, Kawamoto A. Endothelial progenitor cells for postnatal vasculogenesis. Am J Physiol Cell Physiol. 2004; 287: 572-9.

37. Iwata H, Manabe I, Nagai R. Lineage of bone marrow-derived cells in atherosclerosis. Circ Res. 2013; 112: 1634-47.

38. Merkulova-Rainon T, Broquères-You D, Kubis N, Silvestre JS, Lévy BI. Towards the therapeutic use of vascular smooth muscle progenitor cells. Cardiovasc Res. 2012; 95: 205-14.

39. Ross R. Atherosclerosis-an inflammatory disease. N Engl J Med. 1999; 340: $115-26$

40. Libby P. Inflammation in atherosclerosis. Nature. 2002; 420: 868-74.

41. Hansson GK. Inflammation, atherosclerosis, and coronary artery disease. N Engl J Med. 2005; 352: 1685-95.

42. Weissberg PL, Clesham GJ, Bennett MR. Is vascular smooth muscle cell proliferation beneficial? Lancet. 1996; 347: 305-7.

43. Ang AH, Tachas G, Campbell JH, Bateman JF, Campbell GR. Collagen synthesis by cultured rabbit aortic smooth-muscle cells. Alteration with phenotype. Biochem J. 1990; 265: 461-9.

44. Merrilees MJ, Campbell JH, Spanidis E, Campbell GR. Glycosaminoglycan synthesis by smooth muscle cells of differing phenotype and their response to endothelial cell conditioned medium. Atherosclerosis. 1990; 81: 245-54.

45. Campbell GR, Campbell JH, Manderson JA, Horrigan S, Rennick RE. Arterial smooth muscle. A multifunctional mesenchymal cell. Arch Pathol Lab Med. 1988; 112: 977-86.

46. Owens GK. Regulation of differentiation of vascular smooth muscle cells. Physiol Rev. 1995; 75: 487-517.

47. Schwartz SM, deBlois D, O'Brien ER. The Intima : Soil for Atherosclerosis and Restenosis. Circ Res. 1995; 77: 445-65.

48. Campbell JH, Kocher O, Skalli O, Gabbiani G, Campbell GR. Cytodifferentiation and expression of alpha-smooth muscle actin mRNA and protein during primary culture of aortic smooth muscle cells. Correlation with cell density and proliferative state. Arteriosclerosis. 1989; 9: 633-43.

49. Yoshida T, Owens GK. Molecular determinants of vascular smooth muscle cell diversity. Circ Res. 2005; 96: 280-91.

50. Rensen SS, Doevendans PA, van Eys GJ. Regulation and characteristics of vascular smooth muscle cell phenotypic diversity. Neth Heart J. 2007; 15: 100-8.

51. Pauly RR, Passaniti A, Crow M, Kinsella JL, Papadopoulos $\mathrm{N}$, Monticone R, et al. Experimental models that mimic the differentiation and dedifferentiation of vascular cells. Circulation. 1992; 86: 11168-73.

52. Tang Z, Wang A, Yuan F, Yan Z, Liu B, Chu JS, et al. Differentiation of multipotent stem cells contributes to vascular diseases. Nat Commun. 2005; 3: 875 .

53. Carmeliet P. Angiogenesis in health and disease. Nat Med. 2003; 9: 653-60.

54. Frantz S, Vincent KA, Feron O, Kelly RA. Innate immunity and angiogenesis. Circ Res. 2005; 96: 15-26.

55. Moreno PR, Purushothaman KR, Fuster V, O'Connor WN. Intimomedial interface damage and adventitial inflammation is increased beneath disrupted atherosclerosis in the aorta: implications for plaque vulnerability. Circulation. 2002; 105: 2504-11.

56. Fuster V, Moreno PR, Fayad ZA, Corti R, Badimon JJ. Atherothrombosis and high-risk plaque part I: evolving concepts. J Am Coll Cardiol. 2005; 46: 937-54.

57. Ritman EL, Lerman A. The dynamic vasa vasorum. Cardiovasc Res. 2007; 75: 649-58

58. Fadini GP, Madeddu P, Waltenberger J, Fiorina P. Vascular Stem Cells in Diabetic Complications. Exp Diabetes Res. 2012; 2012: 580343.

59. Chandrasekhar KS, Zhou H, Zeng P, Alge D, Li W, Finney BA, et al.
Blood vessel wall-derived endothelial colony-forming cells enhance fracture repair and bone regeneration. Calcif Tissue Int. 2011; 89: 347-57.

60. Keats EC, Khan ZA. Vascular stem cells in diabetic complications: evidence for a role in the pathogenesis and the therapeutic promise. Cardiovasc Diabetol. 2012; 11: 37-46.

61. Khan ZA, Boscolo E, Picard A, Psutka S, Melero-Martin JM, Bartch $\mathrm{TC}$, et al. Multipotential stem cells recapitulate human infantile hemangioma in immunodeficient mice. J Clin Invest. 2008; 118: 2592-9.

62. Khan ZA, Melero-Martin JM, Wu X, Paruchuri S, Boscolo E, Mulliken $\mathrm{JB}$, et al. Endothelial progenitor cells from infantile hemangioma and umbilical cord blood display unique cellular responses to endostatin. Blood. 2006; 108: 915-21.

63. Wu X, Rabkin-Aikawa E, Guleserian KJ, Perry TE, Masuda Y, Sutherland FW, et al. Tissue-engineered microvessels on threedimensional biodegradable scaffolds using human endothelial progenitor cells. Am J Physiol Heart Circ Physiol. 2004; 287: 480-7.

64. Peichev M, Naiyer AJ, Pereira D, Zhu Z, Lane WJ, Williams M, et al. Expression of VEGFR-2 and AC133 by circulating human CD34(+) cells identifies a population of functional endothelial precursors. Blood. 2000; 95: 952-8.

65. Tondreau T, Meuleman N, Delforge A, Dejeneffe M, Leroy R, Massy $\mathrm{M}$, et al. Mesenchymal stem cells derived from CD133-positive cells in mobilized peripheral blood and cord blood: proliferation, Oct4 expression, and plasticity. Stem Cells. 2005; 23: 1105-12.

66. Havelka GE, Kibbe MR. The vascular adventitia: its role in the arterial injury response. Vasc Endovascular Surg. 2011; 45: 381-90.

67. Majesky MW, Dong XR, Hoglund V, Mahoney WM Jr, Daum G. The adventitia: a dynamic interface containing resident progenitor cells. Arterioscler Thromb Vasc Biol. 2011; 31: 1530-9.

68. Kovacic JC, Boehm M. Resident vascular progenitor cells: an emerging role for non-terminally differentiated vessel-resident cells in vascular biology. Stem Cell Res. 2009; 2: 2-15.

69. Pacilli A, Pasquinelli G. Vascular wall resident progenitor cells: a review. Exp Cell Res. 2009; 315: 901-14.

70. Tilki D, Hohn HP, Ergün B, Rafii S, Ergün S. Emerging biology of vascular wall progenitor cells in health and disease. Trends Mol Med. 2009; 15: 501-9.

71. Melero-Martin JM, Dudley AC. Concise review: vascular stem cells and tumor angiogenesis. Stem Cells. 2011; 29: 163-8.

72. Ergün S1, Tilki D, Klein D. Vascular wall as a reservoir for different types of stem and progenitor cells. Antioxid Redox Signal. 2011; 15: 981-95.

73. Armulik A, Genové G, Betsholtz C. Pericytes: developmental, physiological, and pathological perspectives, problems, and promises. Dev Cell. 2011; 21: 193-215.

74. Gerhardt H, Betsholtz C. Endothelial-pericyte interactions in angiogenesis. Cell Tissue Res. 2003; 314: 15-23.

75. Collett GD, Canfield AE. Angiogenesis and pericytes in the initiation of ectopic calcification. Circ Res. 2005; 96: 930-8.

76. Andreeva ER, Pugach IM, Gordon D, Orekhov AN. Continuous subendothelial network formed by pericyte-like cells in human vascular bed. Tissue Cell. 1998; 30: 127-35.

77. Pusztaszeri MP, Seelentag W, Bosman FT. Immunohistochemical expression of endothelial markers CD31, CD34, von Willebrand factor, and Fli-1 in normal human tissues. J Histochem Cytochem. 2006; 54: 385-95.

78. Lin G, Garcia M, Ning H, Banie L, Guo YL, Lue TF, et al. Defining stem and progenitor cells within adipose tissue. Stem Cells Dev. 2008; 17: 1053-63.

79. Klein D, Weisshardt P, Kleff V, Jastrow H, Jakob HG, Ergün S. Vascular wall-resident CD44+ multipotent stem cells give rise to pericytes and smooth muscle cells and contribute to new vessel maturation. 
PLoS One. 2011; 6: 20540.

80. Qian H, Le Blanc K, Sigvardsson M. Primary mesenchymal stem and progenitor cells from bone marrow lack expression of CD44 protein. J Biol Chem. 2012; 287: 25795-807.

81. Díaz-Flores L, Gutiérrez R, Madrid JF, Varela H, Valladares F, Acosta E, $\mathrm{P}$ et al. Pericytes. Morphofunction, interactions and pathology in a quiescent and activated mesenchymal cell niche. Histol Histopathol. 2009; 24: 909-69.

82. Lin CS, Xin ZC, Deng CH, Ning H, Lin G, Lue TF. Defining adipose tissue-derived stem cells in tissue and in culture. Histol Histopathol. 2010; 25: 807-15.

83. Libby P, Ridker PM, Hansson GK. Progress and challenges in translating the biology of atherosclerosis. Nature. 2011; 473: 31725.

84. Korshunov VA, Schwartz SM, Berk BC. Vascular remodeling: hemodynamic and biochemical mechanisms underlying Glagov's phenomenon. Arterioscler Thromb Vasc Biol. 2007; 27: 1722-8.

85. Gutterman DD. Adventitia-dependent influences on vascular function. Am J Physiol. 1999; 277: 1265-72.

86. Torsney E, $\mathrm{Hu}$ Y, Xu Q. Adventitial progenitor cells contribute to arteriosclerosis. Trends Cardiovasc Med. 2005; 15: 648.

87. Wilcox JN, Scott NA. Potential role of the adventitia in arteritis and atherosclerosis. Int J Cardiol. 1996; 54: 21-35.

88. Stenmark KR, Davie N, Frid M, Gerasimovskaya E, Das M. Role of the adventitia in pulmonary vascular remodeling. Physiology. 2006; 21 : 134-45.

89. Sobin SS, Tremer HM, Hardy JD, Chiodi HP. Changes in arteriole in acute and chronic hypoxic pulmonary hypertension and recovery in rat. J Appl Physiol Respir Environ Exerc Physiol. 1983; 55: 144555.

90. Li G, Chen SJ, Oparil S, Chen YF, Thompson JA. Direct in vivo evidence demonstrating neointimal migration of adventitial fibroblasts after balloon injury of rat carotid artery. Circulation. 2000; 101: 1362-5.

91. Ji J, Xu F, Li L, Chen R, Wang J, WC Hu. Activation of adventitial fibroblasts in the early stage of the aortic transplant vasculopathy in rat. Transplantation. 2010; 89: 945-53.

92. Powell DW, Mifflin RC, Valentich JD, Crowe SE, Saada JI, West AB. Myofibroblasts. I. Paracrine cells important in health and disease. Am J Physiol Cell Physiol. 1999; 277: 1-19.

93. Clowes AW, Reidy MA, Clowes MM. Kinetics of cellular proliferation after arterial injury: I: smooth muscle growth in the absence of endothelium. Lab Invest. 1983; 49: 327-33.

94. Tang PC, Qin L, Zielonka J, Zhou J, Matte-Martone C, Bergaya S, et al. MyD88-dependent superoxide-initiated inflammation is necessary for flow-mediated inward remodeling of conduit arteries. J Exp Med. 2008; 205: 3159-71.

95. Galkina E, Kadl A, Sanders J, Varughese D, Sarembock IJ, Ley K. Lymphocyte recruitment into the aortic wall before and during development of atherosclerosis is partially L-selectin dependent. J Exp Med. 2006; 203: 1273-82.

96. Zhou J, Tang PC, Qin L, Gayed PM, Li W, Skokos EA, et al. CXCR3dependent accumulation and activation of perivascular macrophages is necessary for homeostatic arterial remodeling to hemodynamic stresses. J Exp Med. 2010; 207: 1951-66.

97. Mason DP, Kenagy RD, Hasenstab D, Bowen-Pope DF, Seifert RA, Coats $\mathrm{S}$, et al. Matrix metalloproteinase-9 enhances vascular smooth muscle cells migration and alters remodeling in the injured rat carotid artery. Circ Res. 1999; 85: 1179-85.

98. Rodriguez-Menocal L, St-Pierre M, Wei Y, Khan S, Mateu S, Calfa M, et al. The origin of post-injury neointimal cells in the rat balloon injury model. Cardiovasc Res. 2009; 81: 46-53. 